\title{
Forestry and Environment Legislation in Collision - Case Study Serbia
}

\section{Radovan Nevenić}

Institute of Forestry, Kneza Višeslava 3,

11030 Beograd, Serbia nevenic50@yahoo.com

\author{
Zoran Poduška \\ Institute of Forestry, \\ Kneza Višeslava 3, \\ 11030 Beograd, Serbia \\ sm.poduskaz@neobee.net
}

\author{
Renata Gagić - Serdar \\ Institute of Forestry, \\ Kneza Višeslava 3, \\ 11030 Beograd, Serbia \\ katas96@hotmail.com
}

\author{
Ljubinko Rakonjac \\ Institute of Forestry, \\ Kneza Višeslava 3, \\ 11030 Beograd, Serbia \\ ljrakonjac@yahoo.com
}

\section{Abstract \\ Background and purpose: Conflicts in the Serbian for- estry sector have not been very often used as a research topic in our country. This paper presents the results from a case study conducted in the National park 'Fruška gora'. The aim of the study was to explore the collision between forestry and environmental legislation and re- lated institutions and organizations.}

Material and Methods: Data were collected from primary and secondary sources. Primary data were collected through in-depth interviews. Interviews were conducted with the managers of the National park and the representatives of the scientific communities, private forest owners as well representatives from the relevant Ministry. The theoretical framework is a combination of the main conflict elements embedded in the structure of the main aspects like culture, conflict management and policy development.

Results and conclusion: According to the interviewees opinions the roots of the conflict can be found in overlapping jurisdictions of the institutions and organizations in the forestry sector as well as in the implementation of the legislative and management plans. Conflict management strategy is based on sustainable management of protected areas and better implementation of laws.

Keywords: conflict management, National Park Fruška gora, legislative, protected areas

\section{INTRODUCTION}

The Countries of South East Europe (SEE) are currently in process of joining the European Union (EU) and strive to become full member states. The process to join the EU requires SEE Countries to integrate updated policy concerning environmental protection [1] and related legislation into the countries' legislative frameworks.

Protected areas are refuges of tranquility and peace, yet they are also places where conflict occurs.
In a world in which the bio-physical environment and socio-cultural systems are changing rapidly, conflicts involving protected areas are inevitable.

There is no single definition of conflict. According to FAO [2], natural resource conflicts can be seen as disagreement and disputes over access to, control or use of, natural resources. Conflict is also defined as a process in which two or more parties attempt to frustrate the other's goal attainment. The factors underlying conflict are threefold: interdependent, differences in goals, and differences in perceptions [3].

According to Hellström and Reunala [4] main conflicts can be caused by: (I) intensification of forestry operations; (II) increased societal needs like recreation, and (III) growing importance of the environmental movements.

Conflict can represent the productive interaction of competing interests and values, an ever-present function in a dynamic society. Conflicts that are properly addressed can be opportunities for problems to be identified and solved, and progress achieved [5]. Many conflicts, when not managed become counterproductive and destructive, leading to detrimental results and hostile relationships.

Protected area staffs are challenged to respond to conflicts so that unproductive consequences can be avoided while human well being and the natural environment are protected. Conflict will always exist to some degree in every community, but it can often be managed and resolved $[6,7]$.

It is important to emphasize that conflict when managed have the positive impact on relations and even policy development $[8,9]$. If conflicts - even intense ones - raise important political concerns, help to keep the administration alert, motivate creative planning and problem-solving and make sure everyone's opinions are heard, they can work as important catalysts for positive social change and development [10]. 
As the previous research on forest conflicts is limited or non-existent in the SEE region and on the other hand the forest policies in each of the countries are in stages of development, the issue of conflicts can be very significant in identifying the range of interests and related conflicts of different broad stakeholder groups.

\section{MATERIALS AND METHODS}

Fruška Gora is an isolated, narrow, low island mountain in Pannonia plain. The area in which is situated is $80 \mathrm{~km}$ long. Its location, specific geological history and different microclimatic conditions make it very interesting and important to science. In 1948 the government of Pupils Republic of Serbia founded state enterprise called Pupils excursion-place centered in Sremska Kamenica. The aim of this company was establishment, usage and forest complex management for mass picnics and tours of people, together with other tasks for which the forest management unit is competent. In 1952 the first forest management unit basic document has been done, by terrain section of Ministry of forestry. In that time, localization of excursion places has been done, together with landscape architecture, building of roads, footpaths, drink fountains, desks and benches. In 1960, a law proclaiming the Fruska Gora a National Park (NP) was passed. The borders have largely remained the same till today and mark a territory of 25520.00 hectares [11].

NP "Fruška gora" was chosen deliberately, because in this type of protected areas overlapping jurisdiction with regard to forest management between sectors of forestry and nature protection is present.

NP "Fruška gora" is obliged to respect several lows, regarding National parks, forestry, environmental protection, water, fishing, hunting, tourism, cultural heritage, planning and construction, geological researching and mining.

Managing of NP is under the several Laws and regulations, such as:

a. Law on National Parks (Official Gazette Republic of Serbia No 39 from 31st May 1993);

b. Environmental protection law (Official Gazette Republic of Serbia No 66/91 and 135/04);

c. Law on Forestry (Official Gazette Republic of Serbia No 30/10);

d. Spatial Plan of National Park Fruška Gora (Official Gazette of Province Vojvodina 16/04 from 27th August 2004)

e. Management Plan (Faculty of Forestry, Belgrade 2006.)

The objectives of this research were to identify the most important conflicts and to deduce are identified conflicts managed properly? This research was conducted at NP "Fruška gora" in Serbia as well parallel similar protected areas in the five countries in SEE region: Albania, Bosnia and Herzegovina, Croatia, and Macedonia. Each country has one or two case studies.

For that reason the specific open questionnaire was designed and executed in all cases [12]. Questionnaire was designed to capture all four important elements of the conflicts (content, procedure, relations and culture) in targeted group of actors involved in management of protected areas (PA), in government and in related conflicts as well. The data collected through face to face interviews was our primary data. Interviewees were employees in institutions directly or indirectly involved management of PAs Target groups were: employees from the governmental institution related to forestry and nature conservation; public enterprises for forestry; local administration; private

\section{TABLE 1}

List of the interviewees in the case study NP Fruška gora

\begin{tabular}{|l|l|l|}
\hline No & Organisation & Education \\
\hline 1. & National Park "Fruška gora" & Graduate Forest Engineer \\
\hline 2. & National Park "Fruška gora" & Graduate Forest Engineer \\
\hline 3. & National Park "Fruška gora" & Graduate Forest Engineer \\
\hline 4. & $\begin{array}{l}\text { University of Novi Sad, Faculty of Science, Department } \\
\text { of Ecology }\end{array}$ & BSc Ecology \\
\hline 5. & $\begin{array}{l}\text { Ministry of Agriculture, Forestry and Water } \\
\text { Management, Republic Forest Inspection }\end{array}$ & Graduate Forest Engineer \\
\hline 6. & $\begin{array}{l}\text { Ministry of Agriculture, Forestry and Water } \\
\text { Management }\end{array}$ & BSc Economics \\
\hline 7. & Forest community "Beočin" & Graduate Forest Engineer \\
\hline 8. & Forest community "Beočin" & Vocational school \\
\hline 9. & Forest community "Beočin" & BSc Lawyer \\
\hline 10. & Institute for forest protection, Novi Sad & Graduate Forest Engineer \\
\hline
\end{tabular}


forest owners association; protected area administration; scientific institutions.

Since this is the qualitative research there is no strict rule defining the number of interviewees. Researchers take account of the saturation and repetition of the same data and answers and based on that define the number of interviews. Number of case study interviews is presented in the Table 1.

The respondents were asked main questions: are there any conflicts in forestry sector, how the conflicts are managed, how should an organization react to the conflict and did conflicts initiate any changes in your organization and policy process [12]?

Beside the data collected from the interviews all additional data related to the specific case study were collected. Additional data included: documentation, archival records, text analysis, interviews and surveys, direct observations, participant observation and physical artifacts. Main source of information about: behavior, opinion and, values were answers to the open questions which were analyzed qualitatively. This was supported with information on knowledge, educational background and demographics characteristic of the interviewees.

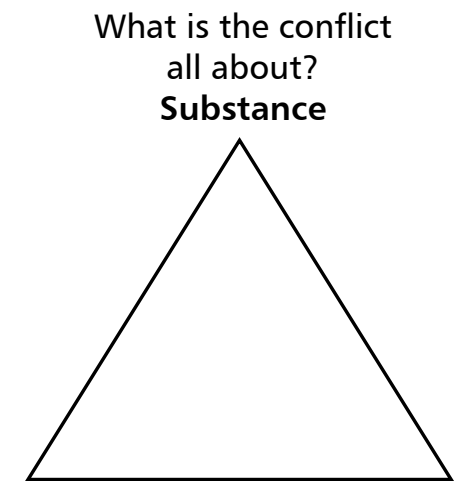

\section{Procedure \\ How is the conflict manifested?}

\section{FIGURE 1 \\ Progressive triangle}

\section{THEORETICAL FRAMEWORK}

Theory defines the conflict in the different ways, using the different terms to explain the word "conflict". The terms such as: struggle, pressure, opposition, aspirations, interaction, cooperation, rivalry, competition are frequently used in the defining of the conflict situation. The theory conflict management framework created by Walker and Daniels [3] includes three elements: substance, process and relations (Figure 1).

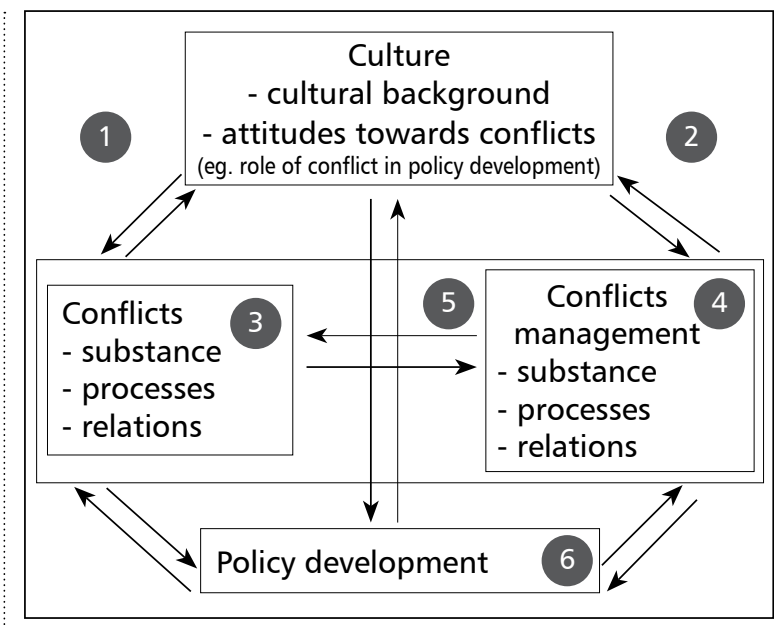

\section{FIGURE 2}

\section{Theoretical framework}

Three elements of conflict also named Progressive triangle and also occurs during the management of conflict. The substance and process are tangible elements of conflict where the relations are based on the personal way of the understanding things. Theoretical framework used is Walker and Daniels [3] is embedded into theoretical framework of Eeva Hellström [10] adding to the theoretical framework fourth important cultural element (Figure 2).

By recognizing major forestry/environmental conflicts in the country, with its themes, actors and intensity, defining its tangibility, it is possible to portrait also conflict management in a triangle of three interrelated dimensions - substance, procedure and relationships - and it will illustrate a number of things regarding various stakeholder's attitudes toward their view on impact on policy development, in order to allow stakeholders meaningful voice in the process.

Since the factor of the "ideal culture" plays an important role for each stakeholder in recognizing selfinterests, it can be applied towards an in-depth analysis of interests.

Upon the basis of improved information a process of "rethinking" is to take place, serving to alleviate the conflict [13].

Conflict management strategies must account for the particular situation in which a conflict occurs. But, complex conflict situations can never be resolved, but they can be managed well, so that the conflict situations do not become destructive. So, the term management is a broad notion that includes, but does not require resolution. It is the way of situation improvement [3].

The role of conflict in actor identity and problem definition: Missing from the discussion so far is the 
recognition of the importance and contribution of social conflict in political discussion. Often conflict is viewed as a destructive force that should be reduced or eliminated. However, without conflict actors cannot define themselves. Actors define themselves in relation to others and "other" is recognized through recognition of difference. Thus, the recognition of difference leads to the establishment of boundaries between "self" and "other" [14].

\section{RESULTS}

The results are divided into groups of elements determining conflict, conflict management elements as well as cultural background and policy development, issues directly affecting or affected by the conflicts.

\section{Conflict and conflict determinants}

Regarding theoretical dividing upon conflict elements, the analyses is set in order according to the gathered data and therefore the substance determining issues, the process indicators as well as the relations defining the conflict.

\section{Substance as a conflict element}

From the data gathered with the interviews, can be concluded that majority of conflicts arise between public and private sector. Some data regarding conflict elements results and therefore for this case study more data besides substance, as well as conflict stage, its beginning and lifespan, main actors involved within conflict, the jurisdiction over the conflicting issue and the powerfulness of the main actors, presented below within the Table 2 .

From the data (Table 2), we can see that conflict have appeared years ago and are still existing. For most of them the causes of appearance are as a result of the new ongoing ecological/environmental initiatives. positive answer and NP offer a service of the maintenance of the meadow. The price of the service was much higher than the financial solvency of the forest community. Therefore the limit of the right to use the private property was imposed, and in turn the expensive service of the maintained was offered.

Overlapping legislation, struggle for competencies, different interests, values and attitudes of forestry and nature conservation sector is likely source of this conflict.

\section{Common denominators}

In NP "Fruška Gora"case study differing management objectives are the key issue. Therefore, these can refer to the values of the conflicting issues (forestry-nature conservation) and interests of the opposed parties [15].

There are several lows, regarding National parks, forestry, environmental protection, water, fishing, hunting, tourism, cultural heritage, planning and construction, geological researching and mining, to be respected. Beside that the restitution process is about to start and will open new possible areas of conflicts where about $50 \%$ of forest areas should be given back to the old owners. The overlapping of several laws consequently lead to poor law enforcement, which could result with new problems sousing new conflicts. This puts parties on the field in more complex situation that before, without proper tools to manage it.

\section{Process}

Ministries responsible for protected areas has jurisdiction over the substance of the conflict. National parks are good examples of areas where various and mutually interdependent stakeholders with differing interests and attitudes struggle to achieve their goals.

\section{TABLE 2}

\section{Conflict element data}

\begin{tabular}{|c|c|c|c|c|c|c|}
\hline $\begin{array}{l}\text { Case } \\
\text { study }\end{array}$ & Conflict substance & $\begin{array}{c}\text { Beginning / } \\
\text { Duration of conflict }\end{array}$ & $\begin{array}{l}\text { Main actors } \\
\text { (stakeholders) }\end{array}$ & $\begin{array}{l}\text { Stage of } \\
\text { conflict }\end{array}$ & $\begin{array}{c}\text { Jurisdiction } \\
\text { over } \\
\text { conflict }\end{array}$ & $\begin{array}{l}\text { More } \\
\text { powerful } \\
\text { actor }\end{array}$ \\
\hline $\begin{array}{l}\text { SER- } \\
\text { Fruska } \\
\text { Gora }\end{array}$ & $\begin{array}{c}\text { meadow maintenance } \\
\text { between PFOs and } \\
\text { NP Fruska gora }\end{array}$ & $\begin{array}{l}\text { NP proclamation } \\
\text { (1960) / Ongoing }\end{array}$ & $\begin{array}{l}\text { NP Fruška gora, } \\
\text { PFOA "Sumska } \\
\text { zajednica" }\end{array}$ & $\begin{array}{l}\text { latent } \\
\text { stage }\end{array}$ & $\begin{array}{l}\text { Institute } \\
\text { for Nature } \\
\text { Protection }\end{array}$ & $\begin{array}{l}\text { Institute } \\
\text { for Nature } \\
\text { Protection }\end{array}$ \\
\hline
\end{tabular}

The substance is disagreement about the management of the meadow. The meadow is privately owned by Forest community "Beočin". The meadow is favorite picnic place of the citizens of town Novi Sad. On the other hand it is the site of numerous protected and rare herbaceous species. The owners intend to fulfill the tourist offer by proper open-air equipment and other serviceable for tourists. This requirement was sent to the Institute of Nature Protection and to the administration of NP "Fruška Gora". There are no
There are significant changes in management of privately owned forests and forest land. The new management plan for Management unit of Forest community "Beočin" was made in year 2007.

\section{Relations}

The main conflict in this case study is between public forestry and environmental sector, public and private sector. The level of trust between the primary 
TABLE 3

Conflict management elements data outlined per case studies

\begin{tabular}{|c|c|c|c|c|c|c|c|}
\hline $\begin{array}{c}\text { Case } \\
\text { study }\end{array}$ & $\begin{array}{c}\text { Conflict } \\
\text { substance }\end{array}$ & CM strategy & $\begin{array}{c}\text { Primary } \\
\text { actors }\end{array}$ & $\begin{array}{c}\text { Power is on } \\
\text { the side of }\end{array}$ & $\begin{array}{c}\text { Professional } \\
\text { background }\end{array}$ & $\begin{array}{c}\text { Organizational } \\
\text { culture }\end{array}$ & $\begin{array}{c}\text { Actor attitudes } \\
\text { towards } \\
\text { conflict }\end{array}$ \\
\hline SER-FRU & $\begin{array}{c}\text { meadow } \\
\text { maintenance, } \\
\text { different } \\
\text { mangement } \\
\text { objectives }\end{array}$ & $\begin{array}{c}\text { Avoidance / } \\
\text { Competitiveness }\end{array}$ & $\begin{array}{c}\text { Fruška } \\
\text { Gora, } \\
\text { PFOA }\end{array}$ & $\begin{array}{c}\text { NP Fruška } \\
\text { gora }\end{array}$ & $\begin{array}{c}\text { NP-foresters } \\
\text { PFOA- } \\
\text { various }\end{array}$ & $\begin{array}{c}\text { NP-traditional, } \\
\text { PFOA-various } \\
\text { perceives no } \\
\text { conflict. } \\
\text { PFOA- } \\
\text { traditional }\end{array}$ \\
\hline
\end{tabular}

parties in these cases varies from distrust or very low level of trust, and that can be seen from answers of the interviewees in all countries.

Primary parties in conflict are: NP "Fruska gora", Institute for Nature Protection and Forest community "Beočin". Secondary parties are: Ministry of Agriculture, Forestry and Water Management, Ministry of Spatial Planning.

The conflict is, according to interviewees, in the latent phase hidden from public view. Relations consist of dialogue, cooperation and participation of all parties in management of protected area.

\section{Conflict management and conflict man- agement determinants}

At the time when the conflict is determined usually subsequently follow up activities towards solving or mitigating the appeared situation. There is variety of activities that can be undertaken in that direction and usually depends on the actor's choices and more or less of the conflict environment attitude and the given situation. Within the Table 3 the conflict management components and the analyzed elements are present.

'The management and solution of the collision between forestry and environmental sector legislation depends to inter-sectoral cooperation. There is obviously lack of collaboration as different view of nature protected area maintenance, process through which parties who see different aspects of a problem can constructively explore their difference and search for solutions that go beyond their own limited vision of what is possible.

\subsection{Substance}

Evidently there are great number of laws and regulations related to the same area. By interpreting and judging them as such, each of the sectors can in theory justify its activity. In practice, it causes misunderstanding, disagreements and even the open conflict between interests of the Association of Private Forest Owners and nature protection requirements.

\subsection{Process}

Although the development of transparent and participatory structures for governing natural resources is an essential step, the process side of conflict management is advance stage. The cooperation between administration of NP and Forest Community result in extraction unique forest management unit, privately owned. Management of this specific Unit differs from management of NP as a whole.

\subsection{Relations}

Conflict management was carried out by Secretariat for Environmental Protection and Sustainable Development who are in the same time stakeholders in the protected areas.

Constructing an environment in which conflicts over natural resources can be dealt with productively will also require new structures and processes for governing natural resources management decisions. Changes to national policies and legal frameworks are needed to accommodate the development of relations between institutions and organizations at various levels. The critical problem is incapacity of stakeholders to provide transparency and accountability to community-based organizations.

\section{Cultural background}

Employees in PFEs with different professional background as conflict parties show differing attitudes to conflicts. Some of them deny the very existence of the conflict some do find conflicts neither negative, nor completely positive.

Traditional values are reflected in the attitudes of the management of the NP as well as in the attitudes of the members of the Forest community. The interviewees from NP use the phrases about "necessity and superiority of the forestry profession in the management of the protected area" since "only foresters have the sufficient scope of knowledge and skills" which can be appropriately used in the management of the NP. The members of the Forest community emphasize the long tradition in management of same forests.

\section{Policy development}

In case study there have been no policy changes made, during or after the conflict management. Some improvement with regard to communication is 
evident. Application of the forestry legislation often presents a problem for employees in forest sector. The employees in the public institutions, public enterprises, and owners of the private forests, as well as experts from the forestry sector and the domain of environment consider that the forestry legislation is not adapted to the needs of the forestry sector. Also there are opposite opinion that the forestry legislation promotes and supports the sustainable forest management in the appropriate way. More than $70 \%$ of the interviewees emphasized that there are difficulties regarding harmonizing the legal regulation of the environmental protection law with the forestry legislation, or think that the harmonisation is not good enough.

\section{DISCUSSION AND CONCLUSIONS}

Origin of the conflicts were related to overlapping or not harmonized law regulative; different way of management of PAs or different property rights. It means that the majorities of conflicts belong to substance part, but in some case studies procedure and relation part were also stressed as components which can improve the substance issue. There was not proper conflict management.

It is evident that there is a great number of laws and sub-legal act which are related with the same area. By interpreting and judging them as such, each of the sectors can in theory justify its activity. In practice, it causes misunderstanding, disagreements and even the open conflict between the forestry and environmental protection legislation, since they are simply used double and impartially as the legal remedy. The views of the people which are in touch with these laws also confirm the theory.

The management and solution of the collision between the forestry sector and legislation which is related to the protected natural resources to a great extent depends upon the inter-sector cooperation, investment in the sectors, as well as monitoring and appraisal of the sectors. The international and regional cooperation becomes a key to the improvement of the legislation and contributes to the investment in the sectors, which is reflected in the connecting of the legal regulations.

IF conflicts are managed, THEN the management of natural resources can become more participative, equative and efficient, rendering benefits to a larger group of stakeholders. Conflicts are actually good, they provide an opportunity to discuss, differ and find common solutions and improve things. If they are not managed then this potential is lost.

Policy processes can be more successful, when they recognize the potential influences of conflicting issues and interests [12].

\section{REFERENCES}

1. UNITED NATIONS 1992 Convention on Biological Diversity. Available at: http://www.cbd.int/doc/legal/cbd-en. pdf (Accessed 20 May 2010)

2. FAO 2000a Conflict and natural resource management. In: Yasmi Y 2003: Understanding conflict in the comanagement of forests: the case of Bulungan Research Forest. International Forestry Review 5 (1) p. 38

3. WALKER G B, DANIELS S E 1997 Foundation of natural resource conflict: Conflict theory and public policy. In: Solberg B, Miina S (eds) Conflict management and participation in land management. European Forestry Institute Proceeding No. 14. Joensuu. Finland, p 7-36

4. HELLSTRÖM E, REUNALA A 1995 Forestry conflicts from the 1950s to 1983. Research Report 3, European Forest Institute, Joensuu, Finland

5. COSIER R A, DALTON D R 1990 Positive Effects of Conflict: A Field Assessment. Int J Confl Manage 1: 81-92

6. FAO 2000b Conflict management series: Proceedings electronic conference on addressing natural resource conflicts through community forestry (January-May 1996). Community Forestry Unit Forests, Trees and People Programme, Forestry Department. In: Yasmi Y 2003: Understanding conflict in the co-management of forests: the case of Bulungan Research Forest. International Forestry Review 5 (1), p 38

7. PRUITT D G, KIM S H 2004 Social conflict: Escalation, stalemate, and settlement (3rd ed.). New York: McGraw-Hill
8. BARON R 1991 Positive effects of conflict: A cognitive perspective: The relative efficacy of four interventions. Employees Responsibilities and Rights Journal 4 (1): 25-36.

9. LEWIS C 1996 Managing Conflicts in Protected Areas. IUCN, Gland, Switzerland, and Cambridge, UK, p xii + 100

10. HELLSTROM E 2001 Conflict cultures: Qualitative comparative analysis of environmental conflicts in forestry. Silva Fennica 2: 1-109

11. www.fruskagora.rs (Accessed 15 May 2011)

12. VULETIĆ, D, STOJANOVSKA M, AVDIBEGOVIĆ M, NEVENIĆ R, PETROVIĆ N, POSAVEC S, HASKA H, PERI L, BLAGOJEVIĆ D 2010 Forest Related Conflicts in the South-East European Region: Regional aspects and Case studies in Albania, Bosnia and Hercegovina, Croatia, Macedonia and Serbia. EFI Proceedings No. 58. ISSN 1237-8801; ISBN 978-052-5453-35-5.

13. KROTT M 2005 Forest Policy Analysis. Springer - EFI. ISBN 1-4020-3478-4 (HB), p 15-20

14. SHANNON M 2003 Cross-Sectoral Policy Impacts Between Forestry and other sectors. Chapter 5. Mechanisms for coordination. FAO Forestry Paper

15. RANTALA T, PRIMMER E, 2003 Value positions based on forest policy stakeholders' rhetoric in Finland. Environ Sci Policy 6: 205-216 